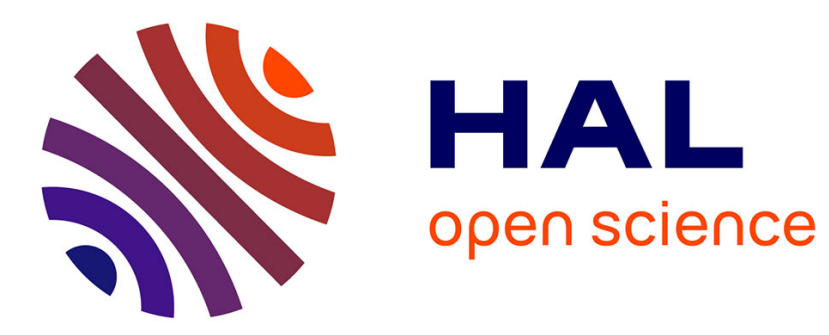

\title{
Changes in soil properties in a fluvisol (calcaric) amended with coal fly ash
}

A. Riehl, F. Elsass, J. Duplay, F. Huber, M. Trautmann

\section{To cite this version:}

A. Riehl, F. Elsass, J. Duplay, F. Huber, M. Trautmann. Changes in soil properties in a fluvisol (calcaric) amended with coal fly ash. Geoderma, 2010, 155 (1-2), pp.67-74. 10.1016/j.geoderma.2009.11.025 . halsde-00546980

\section{HAL Id: halsde-00546980 \\ https://hal.science/halsde-00546980}

Submitted on 30 May 2020

HAL is a multi-disciplinary open access archive for the deposit and dissemination of scientific research documents, whether they are published or not. The documents may come from teaching and research institutions in France or abroad, or from public or private research centers.
L'archive ouverte pluridisciplinaire HAL, est destinée au dépôt et à la diffusion de documents scientifiques de niveau recherche, publiés ou non, émanant des établissements d'enseignement et de recherche français ou étrangers, des laboratoires publics ou privés. 


\title{
Changes in soil properties in a fluvisol (calcaric) amended with coal fly ash
}

\author{
A. Riehl ${ }^{\text {a }}$, F. Elsass ${ }^{\text {b }}$, J. Duplay $^{\text {a,* }}$, F. Huber $^{\text {a }}$, M. Trautmann ${ }^{\text {c }}$ \\ a Laboratoire d'Hydrologie et de Géochimie de Strasbourg, UMR 7517 CNRS, 1 rue Blessig 67084 Strasbourg Cedex, France \\ b Institut National de Recherche Agronomique, route de Saint-Cyr 78026Versailles, France \\ c UMS 830 UDS/CNRS, Laboratoire d'Analyses des Sols et des Formations Superficielles, 3 rue de l'Argonne 67083 Strasbourg Cedex, France
}

\section{A R T I C L E I N F O}

\section{Article history:}

Received 25 March 2009

Received in revised form 17 November 2009

Accepted 23 November 2009

Available online 16 December 2009

\section{Keywords:}

Soil physico-chemical properties

Coal fly ash

Amendment

Soil geochemistry

Microcosms

Leaching

\begin{abstract}
A B S T R A C T
Fluidized bed combustion ash (FBC) is a by-product from coal-fired power stations used for many decades in concrete, cement and brick manufacturing and more recently for trace metal immobilization and pesticide retention in soils. Moreover FBC ash has been recommended by some authors as a soil amendment in agriculture for its nutrient supply. In this study silico-aluminous ( $\mathrm{SiAl}$ ) and sulfo-calcic (SCa) fly ashes have been added to a fluvisol (calcaric) sampled in the Rhine River plain (Germany) in order to investigate the physical, chemical and physico-chemical possible modifications of the amended soil. Earthworms were introduced into microcosms hydrated with a solution of water and $\mathrm{CaCl}_{2}\left(3.710^{-4} \mathrm{mg} / \mathrm{L} ; \mathrm{pH}=6.2\right)$ and stabilized during 7 and 14 weeks. Batch leaching tests were performed during 6 weeks on the amended soil in order to obtain data on the mobilization potential of major elements $\left(\mathrm{NH}_{4}^{+}, \mathrm{Na}^{+}, \mathrm{K}^{+}, \mathrm{Mg}^{2+}, \mathrm{Cl}^{-}, \mathrm{Ca}^{2+}\right.$, $\mathrm{NO}_{3}^{-}, \mathrm{SO}_{4}^{2-}, \mathrm{PO}_{4}^{3-}, \mathrm{H}_{4} \mathrm{SiO}_{4}$ ) and trace elements $(\mathrm{Sr}, \mathrm{Ba}, \mathrm{V}, \mathrm{Zn}, \mathrm{Cu}, \mathrm{Co}, \mathrm{As}, \mathrm{Ni}, \mathrm{Mo}, \mathrm{Cr}, \mathrm{Cd}, \mathrm{Pb})$ during ash-soilwater interactions. The main modification is an increase in $\mathrm{pH}(\approx 12)$ of soil water in soil amended with sulfo-calcic ash, whereas soil pH only slightly changes in the other soil as compared to control soil. This alkaline $\mathrm{pH}$ causes a strong mortality of the macrofauna and a higher mobility of $\mathrm{Co}$, Ni and $\mathrm{V}$ on the contrary to $\mathrm{Cr}, \mathrm{Cu}, \mathrm{Pb}$ and $\mathrm{Zn}$ which are less mobile and more strongly retained by soil. Soil physico-chemical properties remain generally similar to control soil in soil amended with silico-aluminous ash (SiAl) but show major differences in the case of soil amended with sulfo-calcic ash (SCa). The sulfo-calcic ash therefore seems less adapted to integration in soils from an agricultural and farming point of view, contrary to the silicoaluminous ash which increases the cation exchange capacity, thus improving the nutrient and water reserve for plants.
\end{abstract}

(c) 2009 Elsevier B.V. All rights reserved.

\section{Introduction}

In a world context where the management of waste, the efficiency of agriculture as well as the quality of the environment become priorities, the fate of industrial ashes is of great concern. Fluidized bed combustion ash (FBC), a by-product from lignite-fired power stations, has been used in concrete, cement and brick manufacturing for many decades (Saint-Ame, 1998). Recently authors have reported about their efficiency in trace metal immobilization in soils and mine tailings and in pesticide retention in soil (Bertocchi et al., 2006; Majumdar and Singh, 2007; Shaobin Wang and Terdkiatburana, 2008).

Some authors studied the properties of soils after amendment with ash (Aitken et al., 1984; Sikka and Kansal, 1994; Desmukh et al., 2000; Grewal et al., 2001; Kalra et al., 2003). When alkaline, fly ash can be added to increase the $\mathrm{pH}$ of acidic soils; it can also act as a soil modifier to upgrade the physical properties and improve the texture, upgrade the chemical and biological quality of soil (increase in cation

\footnotetext{
* Corresponding author. Tel.: + 333902404 24; fax: + 33390240402 .

E-mail address: jduplay@eost.u-strasbg.fr (J. Duplay).
}

exchange capacity, capacity of water retention, nutrient availability) and thus participate in the optimization of plant growth (Chang et al., 1977; Phung et al., 1979; El-Mogazi et al., 2001).

Douay et al. (2002) have tested the effect of fly ash integration on the bioavailability of toxic elements in calcium carbonate rich soils but noticed a reduced emergence of the seedlings and delayed growth with respect to the control soil. They explained it by a rise in $\mathrm{pH}$ and a poor integration of ashes with the soil. Grumiaux et al. (2007) evidenced toxicity on earthworms after integration of ash in soil and attributed it to soil pH. However, we think that not only pH but also soil texture and structure, and water retention may have played a role in growth delay of seedlings and difficulty for worms to integrate ashes in soil.

Only few studies were devoted to the physico-chemical modifications such as water retention and stability, induced by fly ash amendment into calcium carbonate rich soil. The aim of the present study is to investigate these possible changes of a fluvisol (calcaric) from the Rhine River plain improved by two types of fly ashes (silicoalumineous and sulfo-calcic ashes) considered as decontaminating media. 


\section{Material and methods}

\subsection{Soil sampling and analyses}

The soil used in the present study was taken from a periurban zone in the Rhine River plain, close to Strasbourg city (France). According to the World Reference Base for Soil Resources (IUSS Working Group WRB, 2007) the soil is a haplic fluvisol (calcaric) developed over a carbonated sandy loam formation representative of the river alluvia deposited in the Rhine Graben. It comprises a silty loam layer $(0-30 \mathrm{~cm})$ overlying more sandy layers $(30-100 \mathrm{~cm})$ corresponding to quaternary Rhine alluvia deposited on a deep clayey layer (100$140 \mathrm{~cm}$ ) interpreted as a Rhine overflow deposit. The soil has already been studied by Lahd Geagea (2007) who also traced the environmental pollution in dust, barks and lichen around the site by $\mathrm{Pb}, \mathrm{Sr}$, $\mathrm{Nd}$, and $\mathrm{C}$ isotopic ratios, showing a slight contamination in lead in the $0-18 \mathrm{~cm}$ A0 horizon, as do most of soils in urban and perinatal areas (Elsass et al., 2006). It was therefore interesting to investigate the influence of fly ash amendment on the physico-chemical properties and trace element retention capacity of this type of soil. The site is located in Germany (UTM 32 coordinates: 570413597N 5384604E; Riehl, 2008). After digging in a soil profile under the native forest, samples were collected from the surface $0-30 \mathrm{~cm}$ depth which corresponds to the A horizon.

The physico-chemical characteristics of the fine earth (sieved at $2 \mathrm{~mm}$ ) were determined using the following standard analytical procedures: for $\mathrm{pH}$ and Eh, the standard procedure NF EN 12176; total organic carbon (TOC) by the volume of lost gas during the total dissolution of carbonates by $\mathrm{HCl}$ (volumetric calcimetry, NF ISO 10693); organic matter content (OM) by calcination at $375^{\circ} \mathrm{C}$ during $16 \mathrm{~h}$ after predrying at $150^{\circ} \mathrm{C}$ (NF EN 12875); cation exchange capacity (CEC) by the Metson method (NF X31-130, 1993); structural stability using standard procedure NF X 31-515 (June 2005); bulk mineralogy and clay mineralogy by XRD (Brücker D5000, bulk analysis: $3-65^{\circ} 2 \theta$ scanning angle, clay analysis: $2-30^{\circ} 2 \theta$ scanning angle, $1 \mathrm{~s}-0.02^{\circ}$ upward step, $\mathrm{Cu}$ anticathode, wave length $\lambda_{\mathrm{K} \alpha 1}=1.54056 \AA$, $30 \mathrm{~mA}$ current, $40 \mathrm{kV}$ voltage); C, H, S, N analyses were performed by the SCA CNRS laboratory in Lyon by thermal conductimetry or IR detection after combustion at $1050{ }^{\circ} \mathrm{C}$ for $\mathrm{C}, \mathrm{H}$ and $\mathrm{N}$, and $1350{ }^{\circ} \mathrm{C}$ for $\mathrm{S}$, with a precision of $0.3 \%$; major and trace elements in soil were analysed by ICP-AES and ICP-MS (Jobin Yvon 124 and VG PQ 2+).

\subsection{Fly ash selection and analysis}

Fly ash is a residue of combustion of carbon fossil material in coalfired thermal power plants. Ashes are captured by various filtration processes before gases escape to the atmosphere.

These residues are classified in wastes from power stations and other combustion plants and assigned code number 100102 in the waste list of the European community (decision 2001/118/CE, January 16th, 2001 modifying decision 2000/532/CE as regards the list of waste). They are considered as non hazardous waste contrary to wastes of incineration. Considering French legislation, they are neither classified as special industrial waste (Decree 97-517, May 15th, 1997), nor as dangerous waste (MEDD, 1998, 2002).

Fluidized bed combustion ashes were supplied by Surschiste S.A. and collected from the Carling ( $\mathrm{SiAl}$ ) and Gardanne (SCa) coal thermal power plants, France. They result from the combustion of pulverized coal at low temperature $\left(850-880^{\circ} \mathrm{C}\right)$ and are mainly alkaline.

The chemical composition of SiAl and SCa fly ashes was obtained by ICP-AES analyses; CEC measures were performed by the Metson method. Scanning electron microscopy (SEM) observations and chemical micro analyses were done on a TESCAN Vega 2 XMU Low vacuum, coupled with a micro analytical device (EDAX PEGASUS).

\subsection{Microcosm settings}

Terra-cotta flowerpots $17 \mathrm{~cm}$ deep were used as microcosm settings. Soil samples from the A horizon $(0-30 \mathrm{~cm})$ were homogenized and placed in the microcosms and supplemented by FBC moistened ashes (6\% in mass of the total mass contained in the microcosms). FBC ash was mixed with the soil by hand.

Five media were tested: artificial soil considered as control (T), artificial soil with silico-aluminous ash (TSiAl (7)) or with sulfo-calcic ash (TSCa (7)) incubated for seven weeks in order to stabilize $\mathrm{pH}$ according to the experiments of Grumiaux et al. (2007) and fourteen weeks (TSiAl (14) and TSCa (14) step at which worms may have gained weight. Control soil (T) as well as soils TSiAl (7) and TSCa (7) were duplicated to examine the analytical reproducibility and heterogeneity of the samples.

Earthworms taken from an untreated biological garden were introduced into each microcosm. As they are qualified as structure engineers of soil (Jongmans et al., 2003) they enable reproducing a natural soil structure in microcosms and form aggregates by mixing ash and soil. The first period of microcosm setting procedure was needed as the introduction of ash in soil caused earthworm mortality in TSCa mixtures, probably due to the increase in $\mathrm{pH}$ (Grumiaux et al., 2007). In general even in the best conditions of earthworm survival in microcosms, the mortality was higher in TSCa mixtures than in TSiAl.

Microcosms were regularly hydrated with a solution of water and $\mathrm{CaCl}_{2}\left(3.710^{-4} \mathrm{mg} \mathrm{L}^{-1}, \mathrm{pH}=6.2\right)$. This choice was made to simulate the $\mathrm{pH}$ and ionic strength of natural rainwater, knowing that the rainwater $\mathrm{pH}$ in the region ranges between 6.3 and 6.9 (Elsass et al., 2006) and that the ionic strength is nearly $1.10^{-4} \mathrm{~mol} \mathrm{~L}^{-1}$ (Elsass, personal communication, unpublished). This choice is justified by the fact that the $\mathrm{pH}$ of water is a key parameter affecting the mobility of trace elements in soil but also in ashes (Jankowski et al., 2006). The choice of the addition of $\mathrm{CaCl}_{2}$ to pure water, instead of ammonia as chosen by Jankowski et al. (2006) or of $\mathrm{MgCl}_{2}$ (Rousseau, 2003), was justified considering that an important part of the watering of land comes from the water table or from rivers and has a conductivity of $414 \mu \mathrm{S} \mathrm{cm}^{-1}$. On the other hand the presence of calcium induces flocculation, but as the soil is already saturated in calcium, the addition of $\mathrm{CaCl}_{2}$ will have no side effect (Tessier et al., 1999). Two samples of the watering solution were analysed by spectrometry (ICP-AES and ICP-MS).

After 7 and 14 weeks, the soils were dried and dry sieved through $2000,1000,500,100$ and $50 \mu \mathrm{m}$ mesh sieves and by hand selection with tweezers of 2 to $5 \mathrm{~mm}$ aggregates for structural stability measures. Water adsorption experiments were carried out on less than $500 \mu \mathrm{m}$ aggregates, considering that they are the first aggregates formed by worms after mixing of soil and ash (Marinissen and Didden, 1997; Jongmans et al., 2003), and thus contain the macro and microaggregates the most rich in organo-clay assemblages (Christensen, 1992; Puget, 1997).

\subsection{Isothermal sorption of water vapour}

The method of relative humidity fixed points (HR) was used for the measurements of humidity established at constant ambient temperature over-saturated salt solutions. Relative humidities were chosen according to the scale of relative humidity of air, certified against saturated salt solutions. They are prescribed by the "Organisation Internationale de Métrologie Légale" (1996) according to the description in the standard ISO 483 and in the national standards [NF X 15-014 and 15-119].

Water adsorption experiments were performed at increasing relative humidity $(8.8,14.2,22.5,32.8,45.9,64.4,75.2,84.7,92.3$ and $93 \%$ ). An amount of $0.5 \mathrm{~g}$ of sample previously dried for $24 \mathrm{~h}$ at $110^{\circ} \mathrm{C}$ was deposited in a glass cup of known mass and placed in a plastic desiccator $(2 \mathrm{~L}$ ) where the relative humidity was kept constant and fixed by an over-saturated salt solution. The sample lies close to 
the salt solution, while avoiding the contact with it (MontesHernandez et al., 2003). In that way the hygrothermal balance is quickly and uniformly reached. The desiccators were kept at a constant temperature $\left(25^{\circ} \mathrm{C}\right.$ ) and atmospheric pressure (about $1 \mathrm{~atm})$ in a cool incubator. The evolution of the water content of samples and of a control cup without sample was measured by weighing every day with a digital balance (accuracy $=0.0001 \mathrm{~g}$ ) until equilibrium was reached.

\subsection{Leaching experiments}

The basic principle of the leaching device consists of filtration of percolating water through the soil. The container is a two stage Millipore filtration box for fluid analysis with a $10 \mathrm{~cm}$ internal diameter. At the bottom of the filtration cell were placed successively a pyroxylin $5 \mu \mathrm{m}$ filter, a layer of fibreglass, and a bed of inert silica balls consisting a mixture of $30 \%$ of balls less than $100 \mu \mathrm{m}$ diameter and $70 \%$ of $100 \mu \mathrm{m}$ diameter, a second bed of silica balls with $70 \%$ of balls less than $100 \mu \mathrm{m}$ diameter and $30 \%$ of balls of $100 \mu \mathrm{m}$ diameter; the whole set allows creating a suction gradient and homogenizing the drainage of the percolating water. In that way, no barrier is created and the capillary force is normal or slightly positive (Perdrial et al., 2008).

The leaching water is the same as the solution used to hydrate the soil in microcosms: pure water added with $\mathrm{CaCl}_{2}\left(3.710^{-4} \mathrm{mg} \mathrm{L}^{-1}\right)$. Three times a week during six weeks, soil columns were sprayed with $150 \mathrm{~mL}$ of leaching solution to simulate heavy rain. The eluates were collected every week and analysed by atomic absorption spectrometry (Hitachi Z8200) for $\mathrm{Na}^{+}, \mathrm{K}^{+}, \mathrm{Mg}^{2+}$ and $\mathrm{Ca}^{2+}$, ionic chromatography (Dionex) for $\mathrm{Cl}^{-}, \mathrm{NO}_{2}^{-}, \mathrm{NO}_{3}^{-}, \mathrm{SO}^{2-}, \mathrm{PO}^{3-}, \mathrm{Br}^{-}$, colorimetry (Technicon) for $\mathrm{NH}^{4+}$ and $\mathrm{H}_{4} \mathrm{SiO}_{4}$, and by ICP-MS and AES for trace elements.

\subsection{Statistical analyses}

Paired tests on the different data have been done by the KruskalWallis method with a significance level of 0.05 to compare the soils, and treatments. This tool carries out the non-parametric KruskalWallis test for the comparison of more than two independent samples. It also allows non-parametric two by two comparisons (i.e. multiple or "post hoc" comparisons), taking into account the number of groups in the experiment (Siegel and Castellan, 1988). Moreover a multidimensional statistical treatment, the analysis in principal components (PCA) was applied by using the XLSTAT (2008) software in order to determine the correlations between the different variables of soil and eluate data.

\section{Results}

\subsection{Soil and fly ash characteristics}

The soil constituents are quartz, calcite, dolomite, microcline, albite, and clays. The clayey fraction consists of $40 \%$ of non swelling clay (kaolinite, illite) and $60 \%$ of swelling clay (smectite, vermiculite, mixed-layer illite-vermiculite and illite-smectite). The soil is rich in calcium carbonates (17\% limestone on average), $\mathrm{pH}$ is basic (8.1), Eh slightly negative $(-57 \mathrm{mV}), \mathrm{CEC}$ low (7.5) and the organic matter content ranges between $3.3 \%$ and $6.9 \%$.

Major element analysis shows that soil is $\mathrm{Si}, \mathrm{Ca}$ and $\mathrm{Al}$ rich with a slightly higher $\mathrm{Si}$ content in the A1 horizon. The main difference between $\mathrm{A} 0$ and $\mathrm{A} 1$ is in the texture which is dominantly silty-clayey in $\mathrm{A} 0$ and sandy-silty in A1.

Trace element analyses show that the $\mathrm{Pb}$ content is higher in the surface horizon (42 ppm) as compared to the lower A1 horizon (27 ppm), but still under the fixed impact value (FIV $=400 \mathrm{mg} \mathrm{kg}^{-1}$ dry matter of soil). Fixed impact values are based on studies of the evaluation of toxicity for the human health within the framework of generic scenarios of exposure of the populations to these substances. These values take into account the chronic risks for the health of the populations in relation with the current use of sites (INERIS, 2001; BRGM, 2003). The superficial Pb content confirms the anthropogenic influence in that zone as already noticed by Elsass et al. (2006) for other soils in the Strasbourg urban area. The enrichment in $\mathrm{Pb}$ in the upper horizon can also be related to the organic matter content (6.9\% in $\mathrm{A} 0$ and $3.3 \%$ in $\mathrm{A} 1$ ). All analysed element contents lie below the FIV value (Table 1 ).

The $\mathrm{C} / \mathrm{N}$ ratio rather high (27.4) denotes a weak mineralization according to Duchauffour (1995): the lower the nitrogen content, the higher the $\mathrm{C} / \mathrm{N}$ ratio, the lower the speed of mineralization. This is typical of forest soils under temperate climate.

The fly ashes used in this study can be qualified by their chemical composition (Roy et al., 1981) and their sulphur content (Rakotoarisoa, 2003): SiAl as silico-aluminous and SCa as sulfo-calcic. Quartz, calcite and iron oxides are the common mineral constituents. The SiAl ash also contains feldspar, and SCa ash anhydrite.

The main difference in chemical composition between SiAl and SCa is the silica content ( $43.7 \%$ and $19.9 \% \mathrm{SiO}_{2}$ respectively), the aluminium content (20.5\% and $10.6 \% \mathrm{Al}_{2} \mathrm{O}_{3}$ respectively) and the calcium content $(12.1 \%$ and $35.7 \% \mathrm{CaO}$, respectively). The $\mathrm{S}$ content varies between $2.4 \%$ in $\mathrm{SiAl}$ and $5.9 \%$ in SCa depending on the type of material fired in the thermal power plant (Lecuyer et al., 2001). Trace element contents are above the FIV value for $\mathrm{Cr}$ in SiAl (148 vs. $130 \mu \mathrm{g} \mathrm{g}^{-1}$ ), and for Ni in SCa (398 vs. $140 \mu \mathrm{g} \mathrm{g}^{-1}$ ) (Table 1 ).

The fly ashes SiAl and SCa have a cation exchange capacity (CEC) of 2.2 and $5.8 \mathrm{cmol} \mathrm{kg}^{-1}$ respectively which is very low for SiAl and similar to kaolinite for SCa. The high Ca content results in a high alkalinity of the ashes (13.25 and 13.29 respectively), and Eh is very negative $(-320$ and $-320 \mathrm{mV}$ respectively) indicating reducing conditions in these materials.

Ash particles are fine grained, with a size in general less than $5 \mu \mathrm{m}$ in SiAl and less than $10 \mu \mathrm{m}$ in SCa. On average, fine grained particles dominate in both samples as $62 \%$ are fine silty and $38 \%$ are clayey in SiAl whereas in SCa $85 \%$ are fine silty and $15 \%$ clayey (Table 1 ). Particle shapes are diverse with more rounded grains in the coarser fraction and round, angular or laminar grains in the finer fraction. Coarse silt grains in SiAl look like agglomerates of finer particles whereas in SCa they appear more homogeneous and less aggregated.

\subsection{Changes in soil characteristics after FBC ash addition}

\subsubsection{Chemistry}

After 14 weeks of incubation chemical variations are observed in the different mixtures with respect to the control soil, which are related to the nature of the added ash. Soil TSiAl shows an increase in Al (2.1\% wt ox.) with respect to the control soil. Soil TSCa is characterized by a significant increase in Ca (5.3\% wt ox.). In both cases, there is a decrease in $\mathrm{Si}$ (3.6\% for TSiAl and $10 \%$ for TSCa). The slight decrease in Na in TSCa and slight increase in Fe in TSiAl are within measurement error intervals. The $\mathrm{Mg}, \mathrm{Mn}$, Ti and P contents remain unchanged. The concentrations in $\mathrm{N}$ are low $(0.1-0.2 \%)$ and remain constant in the mixtures as well as the $\mathrm{H}$ content. The concentration in C in TSCa is significantly higher than in the control soil as well as the $S$ content.

When comparing the evolution of the mixtures from 7 weeks to 14 weeks of incubation one can notice an increase in $\mathrm{Si}$ ( $0.6 \%$ with $\mathrm{SiAl}$ and $2 \%$ with SCa) and a loss $\mathrm{Al}$ ( $2.5 \%$ for TSiAl and $0.5 \%$ for TSCa). The Ca content increases in TSiAl and decreases in TSCa (Table 1). Concentrations in $\mathrm{K}$ and $\mathrm{Ti}$ also decrease slightly in both mixtures whereas the concentration in $\mathrm{Mg}$ slightly increases. Concentrations in $\mathrm{Mn}, \mathrm{Na}$ and $\mathrm{P}$ remain unchanged (Table 1). The Fe content is stable for mixtures with $\mathrm{SCa}$ and decreases for mixtures with SiAl. The S content decreases in TSCa after 14 weeks and the $\mathrm{N}$ content remains unchanged. 
Table 1

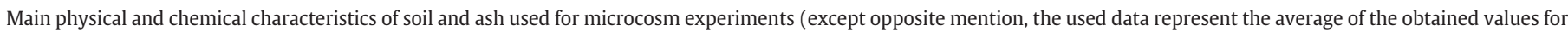
duplicated trials).

\begin{tabular}{|c|c|c|c|c|c|c|c|c|c|c|c|}
\hline & \multirow[b]{2}{*}{ Unit } & \multicolumn{3}{|l|}{ Soil } & \multicolumn{2}{|c|}{ Fly ash } & \multicolumn{4}{|c|}{ Mixtures of soil and fly ash } & \multirow[b]{2}{*}{ FIV } \\
\hline & & $A_{0}$ & $A_{1}$ & $\mathrm{~T}(14)$ & SiAl & SCa & TSiAl (7) & TSiAl (14) & TSCa (7) & T SCa (14) & \\
\hline $\mathrm{pH}$ & & 8.16 & 8.09 & 8.17 & 13.25 & 13.29 & 8.33 & 8.33 & 8.37 & 8.38 & \\
\hline $\mathrm{Eh}^{\mathrm{a}}$ & $\mathrm{mV}$ & -57 & -57 & -57 & - & - & -58 & -66 & -64.5 & -62 & \\
\hline $\mathrm{CaCO}_{3}$ & $\%(w)$ & 17.2 & 16.9 & 12.1 & 4.4 & 17.7 & 11.2 & 12.6 & 19.0 & 17.4 & \\
\hline $\mathrm{CEC}^{\mathrm{a}}$ & $\mathrm{cmol} \mathrm{kg}^{-1}$ & $\begin{array}{l}7.5 \\
7.5\end{array}$ & & 2.2 & 7.5 & 5.8 & 7.1 & 7.9 & 6.9 & 7.3 & \\
\hline$C^{a}$ & $\%$ & 4.11 & & 3.7 & 4.1 & 6.6 & 4.5 & 4.2 & 5.6 & 5.6 & \\
\hline $\mathrm{H}^{\mathrm{a}}$ & $\%$ & 0.76 & & 0.3 & 0.8 & 0.3 & 0.7 & 0.7 & 0.8 & 0.7 & \\
\hline $\mathrm{N}^{\mathrm{a}}$ & $\%$ & 0.15 & & 0.1 & 0.2 & 0.2 & 0.2 & 0.1 & 0.2 & 0.2 & \\
\hline$S^{a}$ & $\%$ & 0.1999 & & 2.4 & 0.2 & 5.9 & 0.2 & 0.2 & 1.6 & 0.8 & \\
\hline $\mathrm{C} / \mathrm{N}^{\mathrm{a}}$ & $\%$ & 27.4 & & 36.6 & 27.4 & 43.7 & 23.1 & 41.9 & 31.0 & 26.5 & \\
\hline Clay & $\%(w)$ & 17.1 & 7.0 & 17.5 & 38.3 & 14.5 & 24.4 & 32.9 & 20.3 & 20.3 & \\
\hline Silt & $\%(w)$ & 64.8 & 20.5 & 54.7 & 61.7 & 85.5 & 75.1 & 67.1 & 75.4 & 63.2 & \\
\hline Sand & $\%(w)$ & 18.1 & 72.6 & 27.7 & 0.0 & 0.0 & 1.1 & 0.0 & 4.3 & 16.5 & \\
\hline $\mathrm{SiO}_{2}$ & $\%(w)$ & 55.1 & 59.3 & 59.1 & 43.7 & 19.9 & 54.9 & 55.5 & 47.0 & 49.0 & \\
\hline $\mathrm{CaO}$ & $\%(w)$ & 9.91 & 10.26 & 12.14 & 12.14 & 35.70 & 11.18 & 12.59 & 19.04 & 17.41 & \\
\hline $\mathrm{Na}_{2} \mathrm{O}$ & $\%(w)$ & 0.91 & 0.98 & 0.89 & 0.33 & 0.18 & 0.83 & 0.80 & 0.75 & 0.73 & \\
\hline $\mathrm{Al}_{2} \mathrm{O}_{3}$ & $\%(w)$ & 6.45 & 6.55 & 6.74 & 20.45 & 10.56 & 11.34 & 8.87 & 8.36 & 7.86 & \\
\hline $\mathrm{MgO}$ & $\%(w)$ & 1.41 & 1.40 & 1.76 & 1.91 & 1.64 & 1.76 & 1.87 & 1.56 & 1.80 & \\
\hline $\mathrm{Fe}_{2} \mathrm{O}_{3}$ & $\%(w)$ & 2.36 & 2.04 & 2.29 & 5.23 & 2.20 & 3.31 & 2.80 & 2.40 & 2.40 & \\
\hline $\mathrm{K}_{2} \mathrm{O}$ & $\%(w)$ & 1.37 & 1.34 & 1.54 & 2.95 & 0.40 & 1.99 & 1.48 & 1.19 & 1.06 & \\
\hline $\mathrm{P}_{2} \mathrm{O}_{5}$ & $\%(w)$ & 0.10 & 0.08 & 0.05 & 0.46 & 0.46 & 0.14 & 0.10 & 0.19 & 0.16 & \\
\hline $\mathrm{MnO}$ & $\%(w)$ & 0.064 & 0.051 & 0.06 & 0.10 & 0.03 & 0.07 & 0.06 & 0.05 & 0.06 & \\
\hline $\mathrm{Sr}$ & $\mu \mathrm{g} \mathrm{g}^{-1}$ & 181 & 247 & 214 & 724 & 1146 & 337 & 282 & 442 & 357 & nd \\
\hline $\mathrm{Ba}$ & $\mu \mathrm{g} \mathrm{g}^{-1}$ & 394 & 359 & 351 & 1667 & 673 & 758 & 519 & 549 & 473 & 625 \\
\hline V & $\mu g \mathrm{~g}^{-1}$ & 39 & 35 & 41 & 182 & 1569 & 75 & 58 & 333 & 259 & 560 \\
\hline $\mathrm{Zn}$ & $\mu \mathrm{g} \mathrm{g}^{-1}$ & 159 & 76 & 106 & 167 & 131 & 160 & 129 & 167 & 123 & 9000 \\
\hline $\mathrm{Cu}$ & $\mu \mathrm{g} \mathrm{g}^{-1}$ & 15 & 11 & 12 & 57 & 30.9 & 46 & 25 & 64 & 27 & 190 \\
\hline Co & $\mu \mathrm{g} \mathrm{g}^{-1}$ & 5.3 & 4.7 & 6 & 26 & 18.0 & 12 & 9 & 9 & 9 & 240 \\
\hline $\mathrm{Ni}$ & $\mu \mathrm{g} \mathrm{g}^{-1}$ & 21 & 20 & 24 & 88 & 398 & 41 & 31 & 127 & 97 & 140 \\
\hline Mo & $\mu \mathrm{g} \mathrm{g}^{-1}$ & - & - & 0.7 & 4.2 & 17.6 & 1,2 & 1,0 & 3.9 & 2,5 & 200 \\
\hline $\mathrm{Cr}$ & $\mu \mathrm{g} \mathrm{g}^{-1}$ & 130 & 60 & 56 & 148 & 122 & 86 & 75 & 65 & 68 & 130 \\
\hline $\mathrm{Cd}$ & $\mu \mathrm{g} \mathrm{g}^{-1}$ & 0.11 & 0.06 & ND & 0.03 & 0.03 & ND & ND & ND & ND & 20 \\
\hline $\mathrm{Pb}$ & $\mu \mathrm{g} \mathrm{g}^{-1}$ & 42 & 27 & 144 & 97 & 7.65 & 859 & 634 & 825 & 520 & 400 \\
\hline
\end{tabular}

nd: not determined.

a Average value of $A_{0}$ and $A_{1}$.

Paired tests show that some trace element contents increase significantly in soils mixed with ash with respect to the control soil. This can be observed after 7 weeks of incubation for $\mathrm{Ba}, \mathrm{Co}, \mathrm{Cu}, \mathrm{Ni}, \mathrm{Pb}, \mathrm{Sr}$, $\mathrm{V}$, and $\mathrm{Zn}$. Samples containing SCa show the highest $\mathrm{Cu}, \mathrm{Ni}, \mathrm{Sr}$, and V contents, whereas samples with SiAl show higher $\mathrm{Ba}, \mathrm{Cr}$, and $\mathrm{Pb}$ contents. Only $\mathrm{Pb}$ exceeds the FIV value in all mixtures (859 and $825 \mu \mathrm{g} \mathrm{g}^{-1}$ respectively).

Element contents normalized to control soil show a strong decrease in $\mathrm{Ba}, \mathrm{Cu}, \mathrm{Co}, \mathrm{Pb}$, and $\mathrm{V}$ after 14 weeks in TSiAl and TSCa (Fig. 1).

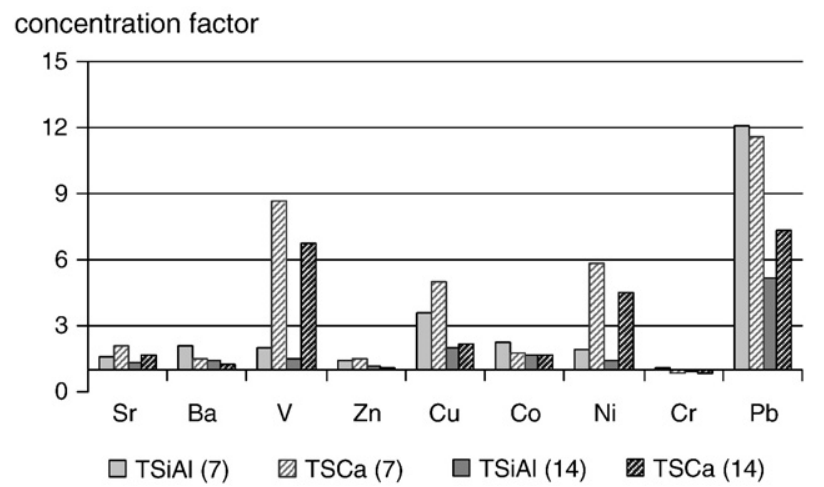

Fig. 1. Trace elements contents normalized to control soil $(\mathrm{T})$ in soils after 7 weeks (TSiAl (7), TSCa (7)) and 14 weeks (TSiAl (14), TSCa(14)) incubation.
According to paired tests comparisons, the most significant differences between control soil $(\mathrm{T})$ and mixtures with ash (TSiAl and TSCa) are in their $\mathrm{Al}, \mathrm{Fe}, \mathrm{K}, \mathrm{Na}, \mathrm{P}, \mathrm{Sr}, \mathrm{V}$ and $\mathrm{Ni}$ contents.

\subsubsection{Physico-chemical characteristics}

3.2.2.1. $\mathrm{C} / \mathrm{N}$ ratio, $\mathrm{CEC}, \mathrm{pH}$, Eh and soil texture. The $\mathrm{C} / \mathrm{N}$ ratio is very high (>20) and influenced by FBC ash composition. In the case of soils mixed with SiAl ash, the ratio is the lowest after 7 weeks whereas it reaches 42 after 14 weeks. For soils mixed with SCa ash, the $\mathrm{C} / \mathrm{N}$ value is 31 after 7 weeks and decreases slightly, reaching 26.5 after 14 weeks, a level equivalent to the control soil.

The cation exchange capacity in TSiAl and TSCa which was lower (7.1 and 6.9 respectively) than in control soil (7.8) after 7 weeks, increases in both samples after 14 weeks, and in a higher extent in the case of TSiAl.

The soil pH ranges between 8 and 8.5. There is no significant difference in the $\mathrm{pH}$ or Eh values $(-50$ to $-75 \mathrm{mV}$ ) for the different samples.

The control soil corresponds to a mixture of the sampled A0 and A1 horizons and can be classified at the border between silty loam and loam. Mixtures TSiAl and TSCa plot in the same domains.

3.2.2.2. Structural stability. Three treatments simulate different conditions of humidity: strong stormy rain or irrigation by submersion for the quick humidification by immersion, moderate rain for slow capillary humidification, and long humidity periods for example in humid winter seasons for mechanical disintegration. The structural stability is high for the control soil (T) and TSCa (Fig. 2). According to the 

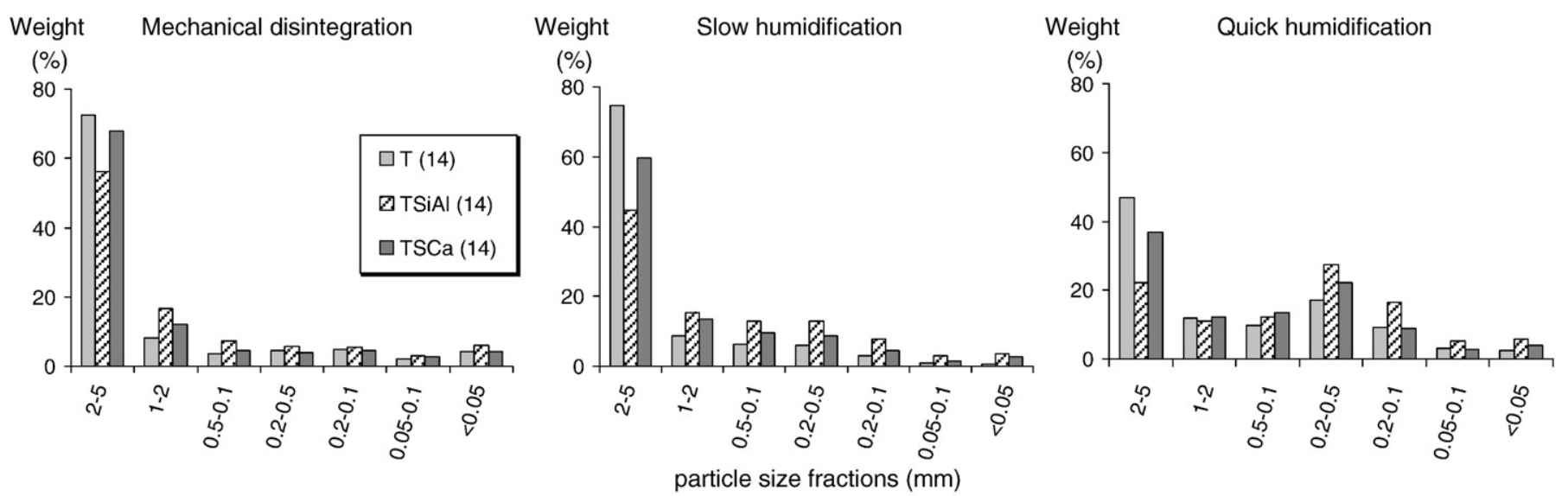

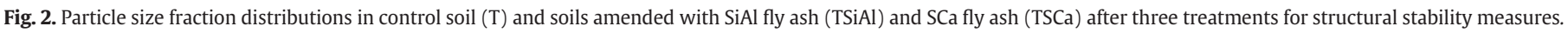

standard AFNOR (2005), they present "a limited or very weak risk in case of runoff and of diffuse erosion of soil", in any climatic condition. The soil mixed with SiAl is much less stable in case of stormy or even moderate rain but it will be more stable in regions with a humid winter climate; in that case the risks of runoff and diffuse erosion will be respectively limited or very weak. On average, the structural stability for the three tests will be maximal for the control soil $\mathrm{T}$ and minimal for the soil mixed with SiAl (TSiAl).

3.2.2.3. Aggregate water adsorption. The sorption kinetics of water vapour is illustrated in Fig. 3 for the two sets of relative humidity (32.8\% and $92 \%$ ).

The experimental data (Table 2) show that the adsorption kinetics of water vapour directly depend on the relative humidity (Fig. 3). In fact, the maximal amount of adsorbed water increases when the relative humidity increases. Moreover the sorption behaviour as a function of relative humidity is different between samples: at $\mathrm{HR}=32.8 \%$ one can observe that the control soil and TSCa show an increase in mass already after 2 days whereas TSiAl shows a sorption effect only after 22 days. The control soil and TSCa show a similar behaviour at $32.8 \% \mathrm{HR}$. At $\mathrm{HR}=92 \%$ all samples show a mass increase after 2 days, but TSiAl and to a greater extent TSCa show a greater ability than control soil to adsorb water. TSCa adsorbs water much faster than TSiAl and T and these differences increase with time. At 92\% HR TSiAl shows a behaviour more similar to control soil.

The isothermal adsorption curves (Fig. 3) are of type III according to IUPAC classification (IUPAC, 1994). This type describes adsorption on macro-porous adsorbents with weak adsorbate-adsorbent interactions. TSCa, TSiAl and control soil are similarly hydrated at low HR and differentiate around 60\% HR where TSCa becomes more hydrated than TSiAl and T. The tendency increases till the experimental maximum HR is reached (97.3\%).

According to Aranovich and Donohue (1998) type III isotherms have steps for low temperatures such as $25^{\circ} \mathrm{C}$, which can be observed in our case for the TSCa water sorption isotherm around 65\% (Fig. 3). Further experiments should be performed and porosity measures should be done to enable giving an interpretation of this phenomenon. But according to literature studies on clay mineral hydration isotherms, several reasons may lead to such steps; among them, the porosity distribution and particle size distribution in aggregates, the nature of the clay mineral, of the organic matter and of the hydrated cations in the organo-mineral aggregates.

\subsection{Soil leaching}

The average $\mathrm{pH}$, conductivity and alkalinity values of eluates sampled during 42 days of leaching are given in Table 3 . The eluate from the sample TSCa is significantly different from T and TSiAl by high $\mathrm{pH}$, alkalinity and conductivity. The eluate from TSiAl has similar $\mathrm{pH}$ but lower alkalinity and higher conductivity than in control soil. The $\mathrm{pH}$ decreases with time in TSCa eluate, whereas it increases slightly in TSiAl. Conductivity decreases with time in all eluates.

The soil mixed with SCa ash releases a great amount of cations and anions, particularly $\mathrm{Ca}^{2+}, \mathrm{SO}_{4}^{2-}$, and $\mathrm{NH}_{4}^{+}$and to a lesser extent $\mathrm{K}^{+}$ and $\mathrm{Cl}^{-}$(Table 4). The soil mixed with SiAl releases $\mathrm{Ca}^{2+}$ to a lesser extent, but on the contrary more $\mathrm{SO}_{4}^{2-}, \mathrm{NO}_{3}^{-}$and $\mathrm{Mg}^{2+}$. The control soil releases more $\mathrm{NO}_{3}^{-}$and $\mathrm{Mg}^{2+}$ than TSCa but less than TSiAl. Most of the released ions are strongly leached during the first 8 days of experiment. No phosphate is detected in all of the eluates.

Trace elements released during the leaching of soils in all samples and at every eluate sampling step are listed in Table 4. The Ni, Mo and $\mathrm{Sr}$ concentrations are higher in TSCa than in TSiAl and T eluates. During the first week of leaching TSCa releases most of the elements whereas TSiAl releases $\mathrm{Sr}$, Ba and little $\mathrm{Ni}, \mathrm{Mo}$ and $\mathrm{Cu}$, and $\mathrm{T}$ releases $\mathrm{Sr}, \mathrm{Ba}, \mathrm{Zn}$ and very low amounts of other trace elements. After 28 days, the amounts of elements released are still higher for TSCa than for TSiAl and T but decrease with respect to the first 8 days. There is a 10 -fold amount of
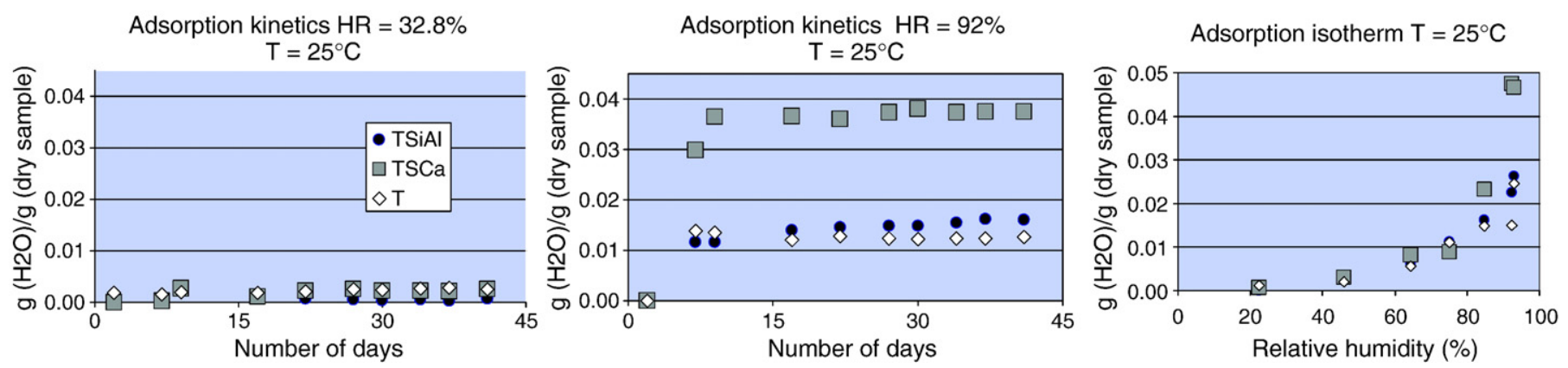

Fig. 3. Kinetics of water adsorption at HR $32.8 \%$ and $92 \%$ in control soil and soils amended with SiAl fly ash (TSiAl) and SCa fly ash (TSCa) after 14 weeks of incubation. 
Table 2

Amount of adsorbed water ( $\left.g_{\mathrm{H} 2 \mathrm{O}} / g_{\text {dry sample }}\right)$ in function of relative humidity (HR) in aggregates of control soil and soils amended with Sd (TSiAl) and Sp (TSCa) after 14 weeks of incubation.

\begin{tabular}{llll}
\hline & \multicolumn{4}{l}{ Mass of adsorbed water $\left(\mathrm{g} \mathrm{H} \mathrm{H}_{2} \mathrm{O} / \mathrm{g}\right.$ dry sample $)$} \\
\cline { 2 - 4 } HR $(\%)$ & $\mathrm{TSiAl}$ & $\mathrm{TSCa}$ & $\mathrm{T}$ \\
\hline 6.4 & $0.00 \mathrm{E}+00$ & $0.00 \mathrm{E}+00$ & $0.00 \mathrm{E}+00$ \\
11.3 & $0.00 \mathrm{E}+00$ & $0.00 \mathrm{E}+00$ & $0.00 \mathrm{E}+00$ \\
22.5 & $0.00 \mathrm{E}+00$ & $7.37 \mathrm{E}-04$ & $1.24 \mathrm{E}-03$ \\
43.2 & $2.73 \mathrm{E}-03$ & $3.09 \mathrm{E}-03$ & $2.06 \mathrm{E}-03$ \\
62 & $6.22 \mathrm{E}-03$ & $8.22 \mathrm{E}-03$ & $5.69 \mathrm{E}-03$ \\
75.3 & $1.12 \mathrm{E}-02$ & $8.86 \mathrm{E}-03$ & $1.10 \mathrm{E}-02$ \\
84.2 & $1.62 \mathrm{E}-02$ & $2.32 \mathrm{E}-02$ & $1.49 \mathrm{E}-02$ \\
92 & $2.26 \mathrm{E}-02$ & $4.75 \mathrm{E}-02$ & $1.49 \mathrm{E}-02$ \\
97.3 & $2.64 \mathrm{E}-02$ & $4.66 \mathrm{E}-02$ & $2.46 \mathrm{E}-02$ \\
\hline
\end{tabular}

released trace elements between TSCa and TSiAl. Moreover the release trend is similar in both cases with an increase in $\mathrm{Sr}, \mathrm{Co}$ and $\mathrm{Ni}$, and a decrease in Mo in the duration of the leaching experiment.

The statistical Kruskal-Wallis tests performed on T, TSiAl and TSCa eluates show that they all three significantly differ by their contents in major ( $\mathrm{Mg}, \mathrm{Ca}, \mathrm{K}$ ) and trace elements $(\mathrm{Sr}, \mathrm{Ba}, \mathrm{V}, \mathrm{Zn}, \mathrm{Cu}, \mathrm{Co}$ and $\mathrm{Ni}$ ). However they are similar in their Fe and Na contents. Concerning $\mathrm{Si}$ and $\mathrm{Al}$ contents, there is a significant difference between control soil and the mixtures with ash.

\subsection{Principal component analysis}

Principal component analysis (PCA) was carried out to determine the correlations between the variables and to identify the possible distribution of trace elements within the different mineral phases in order to better explain their release in eluates. PCA using data matrices includes a) major and trace elements, carbonate, C, S and organic matter content (om\%), CEC, and particle size distribution in soils for the first analysis, and b) chemistry of soils and leachates of soils for the second analysis. The major elements, carbonate, $\mathrm{C}$ and organic matter content account for different phases in the soil.

The first analysis (Fig. 4a) showed that two principal components account for $73.89 \%$ of the total variance in the data; the first factor explaining $49.04 \%$ of the total variance, and the second factor $24.84 \%$ of the remaining explained variance.

The results showed that it is along the first principal component axis that silt, $\mathrm{Cu}, \mathrm{Sr}, \mathrm{P}, \mathrm{Pb}$, and $\mathrm{Zn}$ exhibit positive loading and $\mathrm{Si}, \mathrm{CEC}, \mathrm{Na}$, and sand exhibit negative loading; along the second principal axis, $\mathrm{K}$, clay, $\mathrm{Fe}$, $\mathrm{Al}, \mathrm{Ba}, \mathrm{Co}$, and $\mathrm{Mg}$ showed positive loadings and $\mathrm{Ni}, \mathrm{C}, \mathrm{V}, \mathrm{S}, \mathrm{Ca}, \mathrm{CaCO}_{3}$ showed negative loadings. Organic matter percentage (om\%) and $\mathrm{Cr}$

\section{Table 3}

Average $\mathrm{pH}$, conductivity, alkalinity, cation and anion concentrations ( $\mathrm{mmol} / \mathrm{L}$ ) in eluates of control soil (T) and soils amended with Sd (TSiAl) and Sp (TSCa) leached during 42 days.

\begin{tabular}{|c|c|c|c|c|}
\hline & & $\mathrm{T}$ & TSCa & TSiAl \\
\hline \multirow{7}{*}{$\begin{array}{l}\text { Cations } \\
\text { mmol/L }\end{array}$} & $\mathrm{pH}$ & 7.76 & 11.40 & 8.05 \\
\hline & Conductivity $20^{\circ} \mathrm{C} \mu \mathrm{S} / \mathrm{cm}$ & 361 & 2614 & 1891 \\
\hline & Alkalinity (meq/L) & 0.94 & 12.58 & 2.18 \\
\hline & $\mathrm{NH}^{4+}$ & 0.01 & 1.92 & 0.17 \\
\hline & $\mathrm{Na}^{+}$ & 0.11 & 0.16 & 0.23 \\
\hline & $\mathrm{K}^{+}$ & 0.17 & 0.34 & 0.51 \\
\hline & $\mathrm{Mg}^{2+}$ & 0.20 & 0.01 & 1.59 \\
\hline \multirow{7}{*}{$\begin{array}{l}\text { Anions } \\
\mathrm{mmol} / \mathrm{L}\end{array}$} & $\mathrm{Ca}^{2+}$ & 1.58 & 16.65 & 11.90 \\
\hline & $\sum$ cation charge $(\mathrm{meq} / \mathrm{L})$ & 3.84 & 35.73 & 27.77 \\
\hline & $\mathrm{Cl}^{-}$ & 0.14 & 0.31 & 0.38 \\
\hline & $\mathrm{NO}^{3-}$ & 2.29 & 0.53 & 3.44 \\
\hline & $\mathrm{SO}_{4}^{2-}$ & 0.14 & 9.32 & 10.52 \\
\hline & $\mathrm{PO}_{4}$ & 0.00 & 0.00 & 0.00 \\
\hline & $\sum$ cation charge $(\mathrm{meq} / \mathrm{L})$ & 3.65 & 32.06 & 27.04 \\
\hline Neutral species & $\mathrm{H}_{4} \mathrm{SiO}_{4}(\mathrm{mmol} / \mathrm{L})$ & 0.19 & 0.16 & 0.14 \\
\hline
\end{tabular}

showed a low loading in the F1-F2 plan and are better represented in the F1-F3 plan: they plot apart from other groups and are well correlated together ( $R$ Pearson: 0.74).

This distribution may suggest 4 main groups of elements: 1) the carbonates and sulphates in the silt fraction, 2) the aluminous clay fraction 3) the quartz and feldspars in the sandy fraction and 4) organic matter.

The elements $\mathrm{Co}, \mathrm{Zn}, \mathrm{Cu}, \mathrm{Pb}$ and $\mathrm{Ba}$ plot within the same quadrant as clay, silt, $\mathrm{Fe}, \mathrm{Al}$ and $\mathrm{Mg}$ and opposite to organic matter and sand. $\mathrm{Ni}$, $\mathrm{Sr}$ and $\mathrm{V}$ plot within the same quadrant as carbonate and sulphate, and in the opposite quadrant to sand, Si, Na and CEC. Organic matter percentage (om\%) and $\mathrm{Cr}$ plot in the same quadrant in the F1-F3 plan.

The second analysis of soils and eluates (Fig. 4b) showed that two principal components account for $81.23 \%$ of the total variance in the data; the first factor explaining $52.01 \%$ of the total variance, and the second factor $29.23 \%$ of the remaining explained variance.

The elements $\mathrm{Na}, \mathrm{K}, \mathrm{Ca}$, and $\mathrm{Sr}$ have high positive loadings along the first axis. The elements $\mathrm{P}, \mathrm{Ni}, \mathrm{Cu}$ and $\mathrm{pH}$ have high positive loadings along the first axis as well as positive loadings along the second axis. The elements $\mathrm{Co}$ and $\mathrm{V}$ have positive loadings along F2 in opposition with $\mathrm{Mg}$ whereas $\mathrm{Zn}, \mathrm{Cr}, \mathrm{Pb}, \mathrm{Si}, \mathrm{Al}, \mathrm{Fe}$ and $\mathrm{Ba}$ have high negative loadings along the first axis.

One can distinguish the group along the F1 positive axes which corresponds to the eluates and opposite to the group corresponding to soils (Fig. 4b). Inside the former group, variables $\mathrm{Mg}, \mathrm{Na}, \mathrm{K}$ and $\mathrm{Ca}$ are the common elements in T, TSiAl and TSCa eluates. However Ca is distinct from $\mathrm{Na}$ and $\mathrm{K}$ and strongly correlated to $\mathrm{pH}$, thus characterizing TSCa eluates whereas Mg characterizes T and TSiAl eluates. The trace elements $\mathrm{Ni}, \mathrm{Co}, \mathrm{Cu}$ and $\mathrm{Sr}$ plot in the same quadrant as $\mathrm{Ca}$ and $\mathrm{pH}$ which characterize TSCa eluates. Opposite to that group, $\mathrm{Ba}, \mathrm{Zn}, \mathrm{Pb}$ and $\mathrm{Cr}$ are correlated to the $\mathrm{Si}, \mathrm{Al}$, Fe phases characterizing $\mathrm{T}$ and TSiAl soils. Although positively correlated to $\mathrm{Co}$ and $\mathrm{Pb}, \mathrm{V}$ neither correlates well with SCa eluates, nor with soils and seems distinct from the three main groups. One can notice that no other trace element is strongly correlated to $\mathrm{Na}, \mathrm{K}$ and $\mathrm{Mg}$, the latter characterizing $\mathrm{T}$ and TSiAl eluates.

\section{Discussion}

Several modifications are observed in soils after integration of ashes and reorganization by worms, but overall the soil mixed with SiAl remains similar in physical properties and leaching behaviour to the control soil whereas soil mixed with SCa shows major differences.

The major changes are in the evolution of structural stability. The soil mixed with SiAl shows a weaker stability compared to control soil and TSCa in case of strong leaching. This may be explained by the fact that soil and ash mixtures induced the partial destruction of the initial soil structure and that earthworms formed new casts. This may have induced a decrease in soil aggregate stability as noticed by Binet and Le Bayon (1999) who stated that soil does not always benefit from disturbance by earthworms; newly formed earthworm casts could contribute to soil erosion and losses of nutrients in runoff water. In case of TSCa where the soil water $\mathrm{pH}$ is high and earthworm survival is more difficult than in TSiAl, the aggregates may have been less disturbed and therefore remained more stable. Another noticeable difference between TSiAl and TSCa is the water absorption ability of TSCa. Although CEC and clay fraction are higher in TSiAl and characterize it as is shown in the PCA analysis, the soil mixed with SCa adsorbs water more quickly and in higher amounts. Indeed PCA analysis shows that TSCa is mainly characterized by silt but also clay content. Moreover correlations between water uptake at $92.3 \%$ humidity and silt content are high $(R$ Pearson: 0.84) which indicates that not only clay but also silt content play a major role in water uptake. The behaviour of TSiAl is close to that of the control soil but adsorbs water more slowly. The water sorption difference between TSiAl and TSCa may also be related to the nature of the adsorbent phases. The major effect may be due to organo-mineral 
Table 4

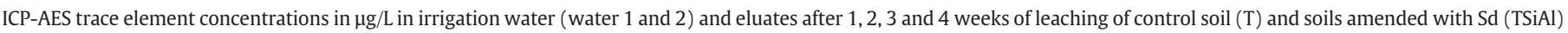
and Sp (TSCa).

\begin{tabular}{|c|c|c|c|c|c|c|c|c|c|c|c|c|c|}
\hline Time (day) & & $\mathrm{Sr}$ & $\mathrm{Ba}$ & V & $\mathrm{Zn}$ & $\mathrm{Cu}$ & Co & As & $\mathrm{Ni}$ & Mo & $\mathrm{Cr}$ & $\mathrm{Cd}$ & $\mathrm{Pb}$ \\
\hline & water 1 & $0.2^{\mathrm{a}}$ & $0.2^{\mathrm{a}}$ & $<$ LD & $1.5^{\mathrm{a}}$ & $0.52^{\mathrm{a}}$ & 0.008 & ND & $<$ LD & 0.7 & 0.18 & $<$ LD & ND \\
\hline & water 2 & $0.2^{\mathrm{a}}$ & $0.1^{\mathrm{a}}$ & $<$ LD & $1.1^{\mathrm{a}}$ & $0.26^{a}$ & 0.004 & ND & $<$ LD & $<\mathrm{LD}$ & 0.15 & $<\mathrm{LD}$ & ND \\
\hline \multirow[t]{3}{*}{8} & $\mathrm{~T}$ & 361 & 225 & $0.8^{\mathrm{a}}$ & 78 & $5.51^{\mathrm{a}}$ & 0.348 & ND & $6.1^{\mathrm{a}}$ & 2.3 & 0.79 & 2.24 & ND \\
\hline & TSCa & 3544 & 456 & 80 & $9.9^{\mathrm{a}}$ & 6.87 & 13.4 & ND & 900 & 291 & 16.1 & 1.25 & ND \\
\hline & TSiAl & 1755 & 428 & $8.1^{\mathrm{a}}$ & $4.8^{\mathrm{a}}$ & 42.1 & 1.84 & ND & $23.7^{\mathrm{a}}$ & 45.7 & 6.94 & 0.49 & ND \\
\hline \multirow[t]{3}{*}{14} & $\mathrm{~T}$ & 258 & 182 & $1^{\mathrm{a}}$ & 107 & $6.29^{a}$ & 0.285 & ND & $5.2^{\mathrm{a}}$ & 2.9 & 0.83 & 1.09 & ND \\
\hline & TSCa & 3315 & 391 & 123 & $3^{a}$ & 9.7 & 19.2 & ND & 890 & 290 & 11.6 & 1.32 & ND \\
\hline & TSiAl & 1834 & 482 & $15.6^{\mathrm{a}}$ & $6.2^{\mathrm{a}}$ & $27^{\mathrm{a}}$ & 3.29 & ND & $26.1^{a}$ & 61.7 & 8.11 & 0.38 & ND \\
\hline \multirow[t]{3}{*}{21} & $\mathrm{~T}$ & 197 & 192 & $1.3^{\mathrm{a}}$ & 44 & $6.99^{\mathrm{a}}$ & 0.219 & ND & $4.3^{\mathrm{a}}$ & 3.3 & 0.85 & 0.29 & ND \\
\hline & TSCa & 4405 & 446 & 195 & $4.2^{\mathrm{a}}$ & 10.6 & 28.2 & ND & 1140 & 425 & 13.1 & 1.53 & ND \\
\hline & TSiAl & 1032 & 274 & $7^{\mathrm{a}}$ & $14^{\mathrm{a}}$ & $9^{a}$ & 1.35 & ND & $13^{\mathrm{a}}$ & 27.0 & $<$ LD & 0.20 & ND \\
\hline \multirow[t]{3}{*}{28} & $\mathrm{~T}$ & 130 & 184 & $1.4^{\mathrm{a}}$ & $19.3^{\mathrm{a}}$ & $6.44^{\mathrm{a}}$ & 0.146 & ND & $3.7^{\mathrm{a}}$ & 2.4 & 0.70 & 0.22 & ND \\
\hline & TSCa & 3965 & 383 & 261 & $7^{\mathrm{a}}$ & 13.1 & 20.2 & ND & 700 & 264 & 11.0 & 1.08 & ND \\
\hline & TSiAl & 1772 & 460 & $11^{\mathrm{a}}$ & $30.5^{\mathrm{a}}$ & $10.92^{\mathrm{a}}$ & 1.84 & ND & $20.1^{\mathrm{a}}$ & 37.1 & 10.2 & 0.38 & ND \\
\hline
\end{tabular}

DL: detection limit.

a Values obtained by ICP-MS.

aggregates which play an important role in water adsorption. In TSCa aggregate stability is higher than in $\mathrm{TSiAl}$, thus favouring the adsorption.

The high $\mathrm{C} / \mathrm{N}$ ratio in the control soil (27) corresponds to a humus type between mull and moder. The $\mathrm{C} / \mathrm{N}$ ratio in TSiAl increases after 14 weeks, the contrary is observed in TSCa but in all cases the $\mathrm{C} / \mathrm{N}$ ratio is high in the mixtures. This denotes a loss of $\mathrm{N}$ by leaching, higher in the case of mixtures with SiAl ash, and with less intensity in the case of mixtures with SCa ash.

That leaching effect is probably in relation with the $\mathrm{pH}$ of the soil solution. Indeed soil pH is only slightly different between the control soil and mixtures of soil and ash (8-8.5) whereas soil water pH drastically changes between TSiAl $(\approx 8)$ and TSCa $(\approx 12)$. This is primarily due to the alkaline minerals contained in the soil and in the ash, such as calcite, dolomite and calcium and magnesium oxides (e.g. lime). This phenomenon has been reported by several authors such as ShepsPelleg and Cohen (1999). When ashes interact with water the $\mathrm{pH}$ increases due to the dissolution of calcium oxides which is favoured by high surface/volume ratios of the fine grained ash particles.

Cappuyns and Swennen (2008) showed that the soil leaching effect is strongly pH dependent. During their experiments, the As, Cd,
$\mathrm{Cu}, \mathrm{Fe}, \mathrm{Ni}$, and $\mathrm{Zn}$ amounts leached are minimum at weakly acid to alkaline solution conditions (6 to 8 ) whereas they are maximum at low $\mathrm{pH}(2)$; these amounts also increase, but to a lesser extent in high alkaline solutions $(\mathrm{pH}>10)$.

These trends are clearly shown in our results and in PCA analysis, where $\mathrm{Co}, \mathrm{Ni}, \mathrm{Cu}$ and $\mathrm{V}$ amounts are high in TSCa where $\mathrm{pH}$ is high $(>10)$. There is a strong correlation between trace elements, Ca and $\mathrm{P}$ amounts in eluates and $\mathrm{pH}$ increase. On the contrary, in control soil and TSiAl eluates where $\mathrm{pH}$ is low, there is no strong correlation between trace elements and the major elements $\mathrm{K}, \mathrm{Na}$, or $\mathrm{Mg}$ which characterize these waters. On the other hand $\mathrm{Cr}, \mathrm{Pb}$ and $\mathrm{Zn}$ are strongly and positively correlated with $\mathrm{Al}$, Fe and Si characterizing soils where $\mathrm{pH}$ is close to 8 . In our experiments, an increase in soil water $\mathrm{pH}$ causes a higher mobility of $\mathrm{Co}, \mathrm{Ni}, \mathrm{V}, \mathrm{Mo}$ and $\mathrm{Sr}$. However concentrations still remain below regulatory leaching limits for waste except for the TSCa eluates. The elements $\mathrm{Cu}, \mathrm{Cr}, \mathrm{Pb}$ and $\mathrm{Zn}$ are less mobile and more strongly retained by soil.

Concerning anions, Cappuyns and Swennen (2008) recorded an increase as a function of $\mathrm{pH}$, in dissolved organic matter, $\mathrm{PO}_{4}^{3-}$, and $\mathrm{SO}_{4}{ }^{2-}$, but $\mathrm{Cl}^{-}$is hardly influenced by $\mathrm{pH}$, what was also observed in our
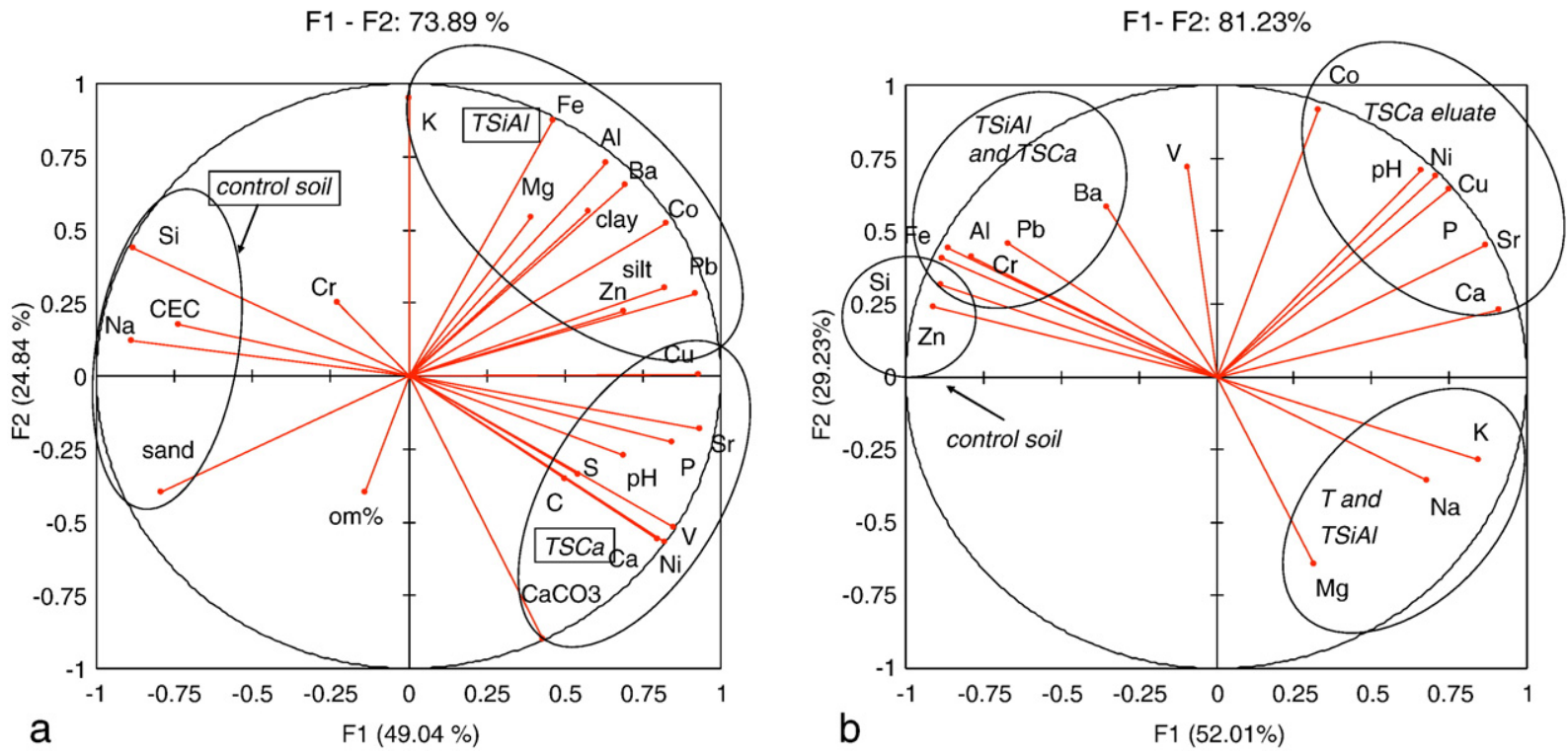

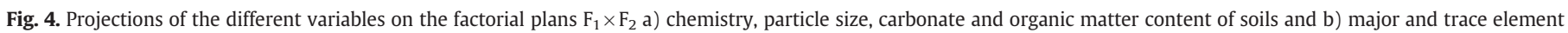
chemistry of soils and eluates. 
experiments. The carbonate content decreases slightly $(-2 \%)$ after 14 weeks in TSCa and increases in TSiAl $(+2 \%)$. Although soil water $\mathrm{pH}$ conditions in TSCa and TSiAl are in favour of $\mathrm{CaCO}_{3}$ conservation, the amount of $\mathrm{Ca}^{2+}$ in leachates is high. A large amount of Ca has been released in eluate during the first 8 days of leaching and much lower amounts are recorded with time. Our experiments show a process similar to what Cappuyns and Swennen (2008) have described.

\section{Conclusion}

In conclusion this work was dedicated to studying in microcosms the physical, chemical and physico-chemical modifications in a fluvisol (calcaric) after integration of a silico-aluminous and a sulfocalcic fly ash. The different results obtained during an experiment period of 14 weeks in microcosms show that SCa ash seems less well adapted to the integration in soils, mainly because of the basicity of the soil solution which it induces. The SiAl ash seems better adapted for amendment from an agricultural and farming point of view as it allows an improvement in CEC, thus furthering the reserve of nutrients and the adsorption of water as a useful reserve for plants. However it lowers the structural stability of the soil.

Finally, it seems important to remind that these studies were made in the conditions of a calcium carbonate rich soil and that the observed reactions are specific to these basic environments and probably very different from those arising in acid soils.

\section{Acknowledgments}

The authors thank Surschiste enterprise for the supply in fly ash, and the LHYGES technical staff of XRD, water and geochemical laboratories for the analyses.

\section{References}

Aitken, R.L., Campbell, D.J., Bell, L.C., 1984. Properties of Australian fly ash relevant to their agronomic utilization. Aust. J. Soil Res. 22, 443-453.

AFNOR, 2005. Mesure de stabilité d'agrégats de sols pour l'évaluation de la sensibilité à la battance et à l'érosion hydrique. NF X 31-515, 10 pp.

Aranovich, G., Donohue, M.D., 1998. Analysis of adsorption isotherms: Lattice Theory predictions, classification of isotherms for gas-solid equilibria, and similarities in gas and liquid adsorption behavior. J. Colloid Interface Sc. 200, 273-290.

Bertocchi, A.F., Ghiani, M., Peretti, R., Zucca, A., 2006. Red mud and fly ash for remediation of mine sites contaminated with $\mathrm{As}, \mathrm{Cd}, \mathrm{Cu}, \mathrm{Pb}$ and $\mathrm{Zn}$. J. Hazard. Mater B134, 112-119.

Binet, F., Le Bayon, R.C., 1999. Space-time dynamics in situ of earthworm casts under temperate cultivated soils. Soil Biol. Biochem. 31, 85-93.

BRGM, 2003. The French approach to contaminated-land management - revision 1. Publication BRGM, BRGM/RP-52276-FR, 148 pp.

Cappuyns, V., Swennen, R., 2008. The application of pHstat leaching tests to assess the pHdependent release of trace metals from soils, sediments and waste materials. J. Hazard. Mater. 158, 185-195.

Chang, A.C., Lund, L.J., Page, A.L., Warneke, J.E., 1977. Physical properties of fly ash amended soils. J. Environ. Qual. 6 (3), 267-270.

Christensen, B.T., 1992. Physical fractionation of soil and organic matter in primary particle size and density separates. Adv. Soil Sci. 20,1-90.

Desmukh, A., Matti, D.B., Bharti, B., 2000. Soil properties as influenced by fly ash application. J. Soils Crop. 10, 69-71.

Douay, F., Dubouguier, H.C., Pruvot, C., Warin, A., 2002. Evaluation de l'intérêt des cendres LFC pour le phytomanagement des sites contaminés par les métaux lourds. Rapport intermédiaire. Lille, Laboratoire Sols Environnement de l'ISA. 50 pp.

Elsass, P., Bouzonville, A., Elsass, F., Fourniguet, G., Gorsy, P., Liewig, N., Morvan, G., Perdrial, N., 2006. Etude de synthèse de l'état des sols sur le territoire de la communauté urbaine de Strasbourg. Rapport final. BRGM/RP-54829-FR. 50 pp.

El-Mogazi, D., Lisk, D.J., Weinstein, L.H.A., 2001. A review of physical, chemical and biological properties of fly ash and effects on agricultural ecosystem. Sci. Total Environ. $74,1-37$.
Grewal, K.S., Yadav, P.S., Mehta, S.C., Oswal, M.C., 2001. Direct and residual effect of fly ash application to soil on crop yield and soil properties. Crop Res. 21, 60-65.

Grumiaux, F., Demuynck, S., Schikorski, D., Lemière, S., Vandenbulcke, F., Leprêtre, A., 2007. Effect of fluidized bed combustion ashes used in metal polluted soil remediation on life history traits of the oligochaeta Eisenia Andrei. Eur. J. Soil Bio. 43, 256-260.

INERIS, 2001. Méthode de calcul des valeurs de constat d'impact dans les sols, INERIS DRC-01-2587/DESP-R01.

IUPAC, 1994. Recommendations. Pure Appl. Chem. 66, 1739.

IUSS Working Group WRB, 2007. World reference base for soil resources 2006, first update 2007. World Soil Resources Reports no. 103. FAO, Rome.

Jankowski, J., Ward, C.R., French, D., Groves, S., 2006. Mobility of trace elements from selected Australian fly ashes and its potential impact on aquatic ecosystems. Fue 85 (6), 243-256.

Jongmans, A.G., Pulleman, M.M., Balabane, M., van Oort, F., Marinissen, J.C.Y., 2003. Soil structure and characteristics of organic matter in two orchards differing in earthworm activity. Appl. Soil Ecol. 24, 219-232.

Kalra, N., Jain, M.C., Joshi, H.C., Chaudhary, R., Pathak, H., Sharma, S.K., Kumar, V., Kumar, R., Harit, R.C., Khan, S.A., Hussain, M.Z., 2003. Soil properties and crop productivities as influenced by fly ash incorporation in soil. Environ. Monit. Assess. 87, 93-109.

Lahd Geagea, M., 2007. Caractérisation chimique et isotopique des aérosols organiques/ inorganiques et détermination de l'impact de la pollution atmosphérique sur l'environnement en milieu urbain. Thèse Université ULP Strasbourg, 185 pp.

Lecuyer, I., Gueraud, S., Bursi, J.M., 2001. Different uses of CFB ash - EDF investigations. EDF R\&D, France. 42nd International Energy Agency - Fluidized Bed Conversion (IEA-FBC), May 10-11, 2001, Sidney, Nova Scotia, Canada.

Majumdar, K., Singh, N., 2007. Effect of soil amendments on sorption and mobility of metribuzinin soils. Chemosphere 66, 630-637.

Marinissen, J.C.Y., Didden, W.A.M., 1997. Influence of the enchytraeid worm Buchholzia appendiculata on aggregate formation and organic matter decomposition. Soil Biol. Biochem. 29 (3/4), 387-390.

MEDD, 1998. Ministère de l'Environnement et du Développement Durable. Arrêté du 8 janvier 1998 fixant les prescriptions techniques applicables aux épandages de boues sur les sols agricoles pris en application du décret $n^{\circ}$ 97-1133 du 8 décembre 1997 relatif à l'épandage des boues issues du traitement des eaux usées. JO 31 janvier 1998, NOR: ATEE9760538A

MEDD, 2002. Ministère de l'Environnement et du Développement Durable, Décret no 2002-540 du 18 avril 2002 relatif à la classification des déchets. JO 20 avril 2002, NOR : ATEP0190045D

Montes-Hernandez, G., Duplay, J., Martinez, L., Géraud, Y., Rousset-Tournier, B., 2003. Influence of interlayer cations on the water sorption and swelling-shrinkage of MX80 bentonite. Appl. Clay Sci. 23 (5-6), 309-321.

Organisation Internationale de Métrologie Légale, 1996. Échelle d'humidité relative de l'air certifiée par rapport à des solutions saturées de sels, 10 pp.

Perdrial, N., Elsass, F., Liewig, N., 2008. New technique for in-situ sampling of particulate matter and colloids in soil and atmospheric fallout. Colloids Surf., A Physicochem. Eng. Asp. 317, 742-746.

Phung, H.T., Lam, H.V., Lund, L.J., Page, A.L., 1979. The practice of leaching Boron and salts from fly ash amended soils. Water Air Soil Pollut. 12, 247-254.

Puget, P., 1997. Distribution des matières organiques dans des agrégats de sols limoneux cultivés. Conséquences sur la stabilité structurale des agrégats et sur la biodégradation des matières organiques. Thèse Université Paris XII-Val de Marne, 164 pp.

Rakotoarisoa, Z. 2003. Prédiction du comportement environnemental des résidus de procédés thermiques (RPT) utilisés comme matériaux de travaux plublics. Thèse INS Lyon, $254 \mathrm{pp}$

Riehl, A., 2008. Réactivité d'un sol en zone urbaine industrialisée après incorporation d'un polluant et de cendres de remédiation Rapport stage M2, Université ULP Strasbourg, $30 \mathrm{pp}$.

Rousseau, M., 2003. Transport préférentiel de particules dans un sol non saturé: de l'expérimentation en colonne lysimétrique à l'élaboration d'un modèle à base physique. Thèse INP Grenoble, 216 pp.

Roy, W.R., Thierry, R.G., Schuller, R.M., 1981. Coal fly ash: a review of the literature and proposed classification system with emphasis on environmental impacts. Environ. Geol. Notes 96, 1-69.

Saint-Ame, A., 1998. Surschiste et la valorisation des cendres de charbon. Mines et Carr. 80 18-21.

Shaobin Wang, T., Terdkiatburana, M.O., 2008. Single and co-adsorption of heavy metals and humic acid on fly ash. J. Separation Purif. Technol. 58, 353-358.

Sheps-Pelleg, S., Cohen, H., 1999. Evaluation of the leaching potential of trace elements from coal ash to the (goundwater) aquifer. International Ash Utilization Symposium on Materials for the Next Millennium Lexington, KY, U.S., Center for Applied Research. University of Kentucky.

Siegel, S., Castellan, N.J., 1988. In: Siegel, S., Castellan, N.J. (Eds.), Non Parametric Statistics for the Behavioral Sciences. McGraw-Hill, New York.

Sikka, R., Kansal, B.D., 1994. Characterization of thermal power plant fly ash for agronomic purposes and to identify pollution hazards. Bioresour. Technol. 50, 269-273.

Tessier, D., Bigorre, F., Bruand, A., 1999. La capacité d'échange: outil de prévision des propriétés physiques de sols. C. R. Acad. Agric. Fr. 85 (2), 37-46. 